\title{
Strusky a železo z experimentální tavby železa realizované na hradě Buchlově (jv. Chřiby) v roce 2018
}

\author{
Slags and iron from experimental smelting of iron realized at the Buchlov Castle \\ (Chřiby Mts., Czech Republic) in 2018
}

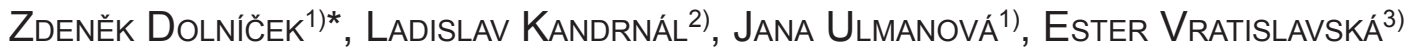 \\ A PAVEL HOJAČ 4$)$ \\ ${ }^{1)}$ Mineralogicko-petrologické oddělení, Národní muzeum, Cirkusová 1740, 19300 Praha 9; \\ *e-mail: zdenek.dolnicek@nm.cz \\ 2)Kameňák 145, 69650 Moravany u Kyjova \\ 3)Vlastivědné muzeum, Palackého 70, 69701 Kyjov \\ 4)Komenského 740, 69701 Kyjov
}

Dolniček Z, Kandrnál L, Ulmanová J, VRatislavská E, Hojač P (2020) Strusky a železo z experimentální tavby železa realizované na hradě Buchlově (jv. Chřiby) v roce 2018. Bull Mineral Petrolog 28(1): 58-68 ISSN 2570-7337

\begin{abstract}
During experimental smelting of iron in a replica of historical shaft furnace, which was held at the Buchlov Castle in 2018, charcoal and Mn-enriched pelosiderite-limonite iron ore from the locality Strážovice near Kyjov were used. The obtained furnace slag is practically completely formed by glass phase; only rare small domains also contain olivine. The glass phase is compositionally heterogeneous and contains $0.7-10.7$ wt. \% $\mathrm{MnO}$, whereas olivine corresponds to fayalite with elevated contents of tephroite (ca. $12 \mathrm{~mol}$. \%), forsterite (ca. $4 \mathrm{~mol}$. \%) and dicalciumsilicate (1 mol. \%) components. The produced metallic iron is also compositionally heterogeneous, rich in phosphorus and in places it contains small spherical inclusions of pyrrhotite. The phase composition of slag differs significantly from those of typical iron slags. The reason can be seen either in anomalous chemical composition of used ore (the elevated contents of Mn could potentially act as an inhibitor of crystallization), or in too high temperatures during smelting (the phase relations in metallic iron suggest temperatures exceeding $1500^{\circ} \mathrm{C}$ ) in combination with rapid cooling of the furnace content after finishing of smelting. Both phase composition of slag as well as chemical composition of individual slag phases and metallic iron are significantly different from those of local historical artefacts from the period of usage of technology of direct production of iron. These findings do not support the idea that local pelosiderite iron ores were used for production of iron already during this early period.
\end{abstract}

Key words: archaeometallurgy, experimental iron smelting, slags, phosphorus-rich iron, pelosiderite, limonite, Chřiby Mts.

Obdrženo 28. 1. 2020; prijato 3. 4. 2020

Úvod

Archeometalurgické experimentální tavby kovů, praktikované už více než 100 let, jsou důležitým doplňkovým zdrojem informací o starých, často již nepoužívaných technologiích výroby kovů z rud. Přinášejí cenné informace o dávných technologických postupech, které neIze z dochovaných archeologických situací a artefaktů již dnes prímo zjistit. $V$ českých zemích mají dlouholetou tradici zejména experimentální tavby železa, jejichž primárním účelem bylo ověření funkčnosti rekonstrukcí různých typů pecí, definovaných na základě četných archeologických nálezů metalurgických zařizení na našem území (Pleiner 1969; Stránský et al. 1978; Souchopová 1986; Barák 1995). V poslední době narůstá na významu i popularizační aspekt experimentálních taveb, nebot' tyto akce prístupnou a atraktivní formou prezentují výsledky vědeckého bádání široké veřejnosti.

Primárně popularizační význam měla i experimentální tavba železa, uskutečněná v roce 2018 na nádvoří hradu Buchlov (jv. Chřiby, asi 10 km zsz. od Uherského
Hradiště; obr. 1). Tato akce však byla zajímavá i z odborného pohledu. Pro tavbu byla použita železná ruda z nedalekého bývalého ložiska pelosideritů u Strážovic u Kyjova, těženého $v 19$. století pro potřeby místní železářské hutě. Pelosiderit ( $\mathrm{z}$ něj zvětráváním vzniklý limonit) $z$ této lokality se vyznačuje dosti specifickým chemickým složením, zejména variabilními obsahy $\mathrm{Mn}$ (stopy až 21.9 hm. \% MnO; Burkart 1953; Křivánek 2015); z toho důvodu bude zajímavé posoudit, jak se toto odlišné chemické složení použité rudy projeví na fázovém složení vzniklé strusky a také na chemickém složení jednotlivých struskových fází a vyredukovaného železa. Podle některých názorů byly pelosideritové železné rudy $v$ minulosti využívány $\mathrm{k}$ výrobě železa nejen $\mathrm{v}$ moderní době, ale $\mathrm{i}$ v podstatně dřivějších obdobích (např. Kolbinger 2011). Pro posouzení opodstatněnosti této hypotézy je znalost fázového složení a chemismu jednotlivých fází strusky, vzniklé ze vsázky prokazatelně obsahující místní rudu, klíčovým poznatkem. $Z$ toho důvodu jsme struskám $z$ této tavby věnovali bližší pozornost. 


\section{Tavba železa na Buchlově 2018}

Pro potřeby experimentální tavby byla v předstihu zhotovena replika nadzemní šachtové pece (obr. 1). Pec, dyznový panel i dyzna byly vymodelovány z průmyslové šamotové hlíny. Jako palivo bylo použito komerčně dostupné bukové a dubové dřevěné uhlí. Ve zhotovené peci byly realizovány dvě tavby $v$ rozmezí dvou dnů. Pro první tavbu byla použita jako vsázka výhradně místní železná ruda, získaná autory tohoto příspěvku povrchovým sběrem na opuštěném ložisku pelosideritů na Strážovském vrchu (v některých mapách Babylon) u Strážovic u Kyjova. Nasbírané volné konkrece pelosideritu a limonitu (vzniklého zvětráváním pelosideritových konkrecí) měly světle až tmavě rezavou barvu a velikost maximálně $15 \mathrm{~cm}$. Ruda byla $v$ předstihu před tavbou vypražena a ručně nadrcena na frakci 2 - $5 \mathrm{~mm}$. Pro druhou tavbu byl použit stejně předběžně upravený komerční indický hematit. Během taveb nebyly do vsázky přidávány žádné struskotvorné či jiné přísady. Ruda a dřevěné uhlí byly po rozhoření pece přisazovány $v$ poměru $1: 1$. Po vsazení zhruba poloviny připravené rudy (cca $7 \mathrm{~kg}$ ) byl učiněn pokus o odpuštění části strusky (proražením malého otvoru ve spodní části dyznového panelu), který však nebyl úspěšný (žádná kapalná struska neodtekla). Poté bylo pokračováno v tavbě a $v$ přisazování zbytku rudy (dalších cca $7 \mathrm{~kg}$ ) a uhlí. Po vyhoření většiny vsazeného obsahu pece byl dyznový panel odstra-

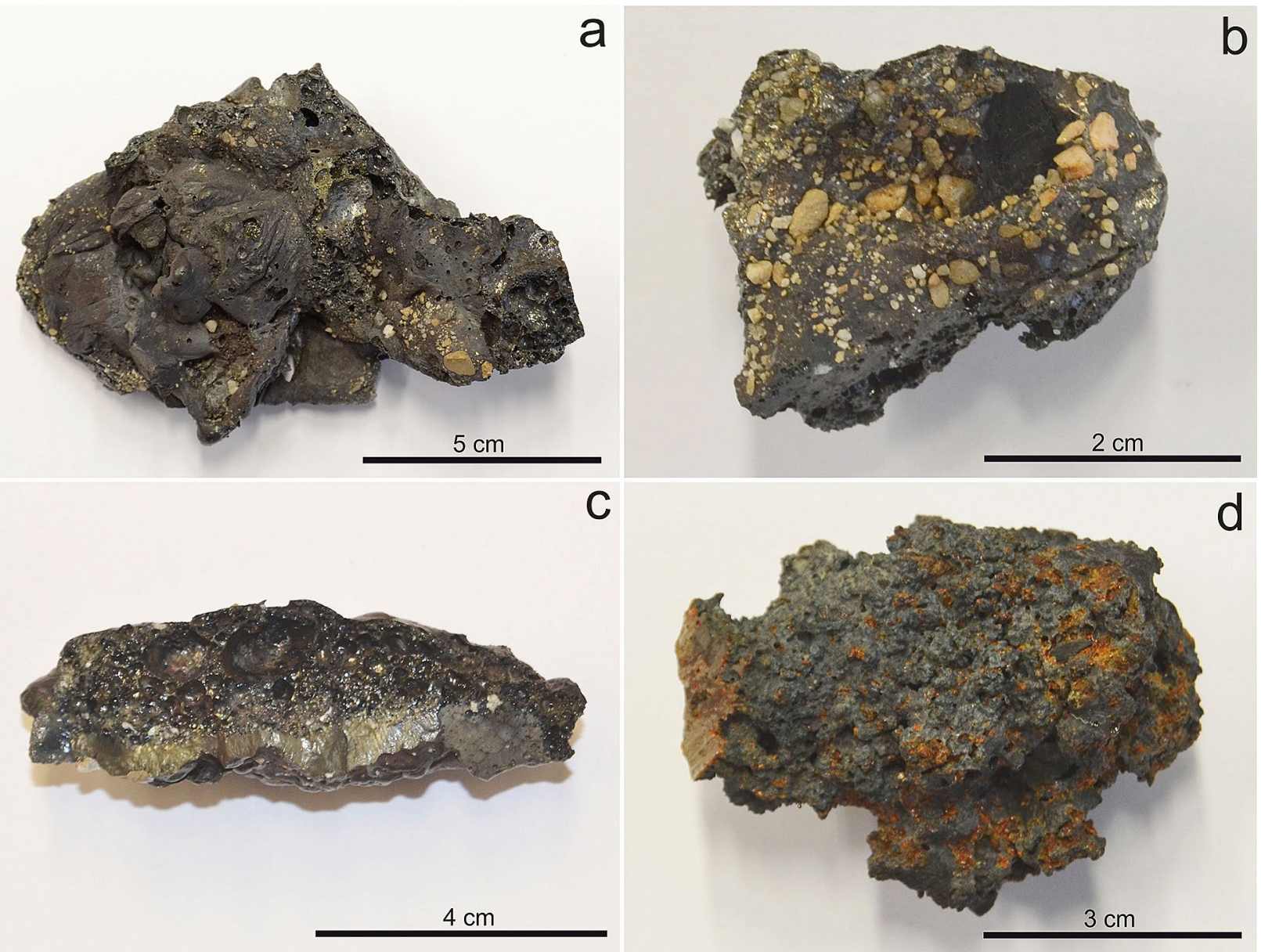

Obr. 2 Makroskopický vzhled studovaných vzorků. a - vzorek STR-1, struska, pohled na horní povrch vzorku. b- vzorek STR-2, struska, pohled na spodní povrch vzorku s připečenými křemennými zrny a fragmentem dřevěného uhlí. c - vzorek STR-3, struska, príčný lom vzorkem. Spodní, méně bublinatá partie bílozelené barvy je tvořena devitrifikovaným sklem. $d$-vzorek STR-4, železná houba, pohled na horní část vzorku. Makrofota J. Ulmanová. 
něn (obr. 1) a z pece byl ještě za žhava vylomen nístějový struskový slitek obsahující vyredukované železo.

\section{Materiál a metodika}

U vzorků, které měli autoři předložené zprávy k dispozici, nebyla známa jejich původní pozice v peci, ani to, ze které z obou realizovaných taveb jednotlivé kusy strusek pocházejí.

Nábrusy ze studovaných strusek a železa byly zhotoveny zalitím odřezků vzorků do epoxidové pryskyřice a naleštěním pomocí diamantových suspenzí. Dokumentace nábrusů $v$ odraženém světle byla provedena na odrazovém polarizačním mikroskopu Nikon Eclipse ME600. Následně byl preparát potažen uhlíkovým filmem o tloušt'ce $30 \mathrm{~nm}$ a studován na elektronové mikrosondě Cameca SX-100 v laboratoři Mineralogicko-petrologického oddělení Národního muzea $v$ Praze. Na přístroji byly porízeny snímky ve zpětně odražených elektronech (BSE), provedena identifikace jednotlivých fází pomocí energiově disperzních (EDS) spekter a kvantitativně měřeno chemické složení vybraných fází ve vinově disperzním (WDS) modu. Při bodových analýzách skloviny, fayalitu a hematitu bylo použito urychlovací napětí $15 \mathrm{kV}$, fokusovaný elektronový svazek o průměru cca $0.7 \mu \mathrm{m}$ a proud svazku $10 \mathrm{nA}$ (fayalit, sklovina), resp. $30 \mathrm{nA}$ (hematit). Ve všech analýzách skloviny a fayalitu byly měřeny obsahy
$\mathrm{Al}, \mathrm{Ba}, \mathrm{Ca}, \mathrm{Cl}, \mathrm{Cr}, \mathrm{F}, \mathrm{Fe}, \mathrm{K}, \mathrm{Mg}, \mathrm{Mn}, \mathrm{N}, \mathrm{Na}, \mathrm{Ni}, \mathrm{P}, \mathrm{S}, \mathrm{Si}, \mathrm{Sr}$, $\mathrm{Ti}, \mathrm{V}, \mathrm{Zn}$ a $\mathrm{Zr}$ a v hematitu $\mathrm{Al}, \mathrm{Ca}, \mathrm{Cr}, \mathrm{Fe}, \mathrm{Mg}, \mathrm{Mn}, \mathrm{Ni}, \mathrm{P}$, $\mathrm{Si}, \mathrm{Ti}, \mathrm{V}, \mathrm{Zn}$ a Zr. Použité analytické čáry a standardy: albit $(\mathrm{NaK \alpha})$, almandin (AlKa, FeKa), apatit (CaKa, PKa), baryt $(\mathrm{BaL} \beta), \mathrm{BN}(\mathrm{NK} \alpha)$, celestin (SKa, SrL $\beta)$, diopsid (MgKa), halit $(\mathrm{ClK \alpha})$, hematit (FeKa), LiF (FKa), Ni (NiKa), rodonit $(\mathrm{MnK \alpha})$, sanidin $(\mathrm{KK} \alpha)$, wollastonit $(\mathrm{CaK \alpha}, \mathrm{SiK} \alpha)$ a zinkit (ZnKa). Při bodových analýzách kovového železa a sulfidů bylo použito urychlovací napětí $25 \mathrm{kV}$, proud svazku $20 \mathrm{nA}$ a průměr elektronového svazku $0.7 \mu \mathrm{m}$. Použité standardy a analytické čáry: $\mathrm{Ag}(\mathrm{AgL} \alpha), \mathrm{Au}(\mathrm{AuM \alpha}), \mathrm{Bi}_{2} \mathrm{Se}_{3}$ $(\mathrm{BiM} \beta), \mathrm{CdTe}(\mathrm{CdL} \alpha)$, Co (CoKa), CuFeS ${ }_{2}$ (CuKa, SKa), $\mathrm{FeS}_{2}$ (FeKa), GaAs (GaL $\left.\alpha\right)$, Ge (GeLa), HgTe (HgLa), InAs (InL $\alpha), \mathrm{Mn}(\mathrm{MnK} \alpha), \mathrm{NaCl}(\mathrm{ClK \alpha}), \mathrm{NiAs}(\mathrm{AsL} \beta), \mathrm{Ni}$ (NiKa), PbS (PbMa), PbSe (SeL $\beta)$, PbTe (TeLa), $\mathrm{Sb}_{2} \mathrm{~S}_{3}$ $(\mathrm{SbL} \alpha), \mathrm{Sn}(\mathrm{SnL} \alpha)$ a ZnS (ZnKa). Celkové chemické složení kovových kapek bylo měřeno za stejných podmínek jako jednotlivé bodové analýzy, při analýze však byl snímán signál z co největší plochy dané kapky, aniž by ovšem byla zahrnuta i okolní struska. Měřící časy na píku se pohybovaly mezi 10 a 30 s (pro dusík 150 s), měřící časy pozadí trvaly polovinu času měření na píku. Načtená data byla přepočítána na hm. \% s použitím standardní PAP korekce (Pouchou, Pichoir 1985). Obsahy měřených prvků, které nejsou uvedeny $v$ níže uvedených tabulkách, byly ve všech případech pod mezí stanovitelnosti.
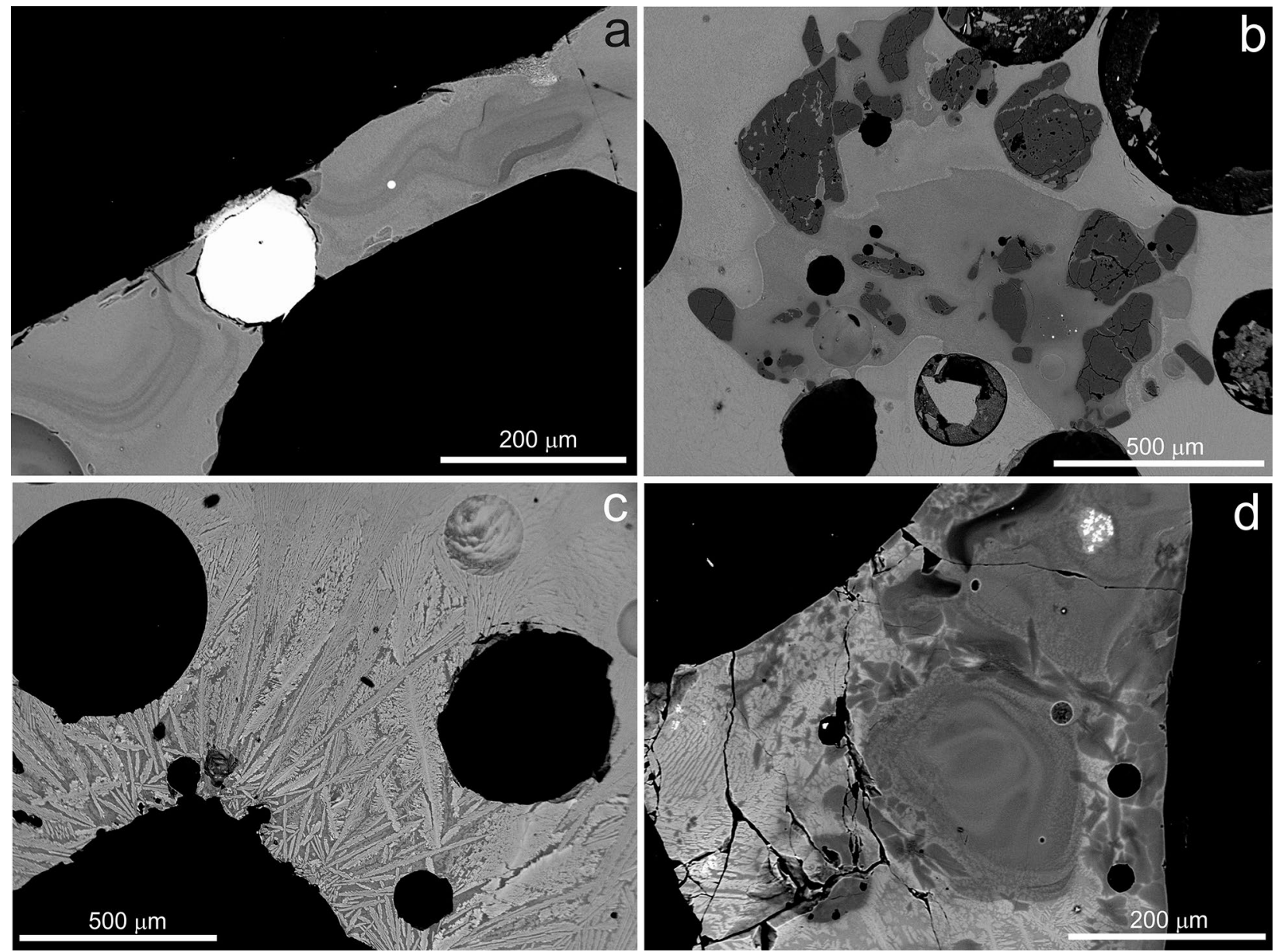

Obr. 3 Stavba a fázové složení studovaných strusek na BSE snímcích. a - sklovina se zřetelnou fluidální stavbou, uzavírající kapky železa (bílé) a bubliny (černé), vzorek STR-1. b - shluk neroztavených zrn křemene (nejtmavši), uzavřených ve sklovině vzorku STR-1. Tmavši lem kolem křemenných zrn je tvořen sklovinou s vyšším obsahem $\mathrm{SiO}_{2}$. C - peřičkovité krystaly fayalitu ve vzorku STR-3. d - zonální sklovina přeplněná drobnými krystaly fayalitu $v$ asociaci se shlukem kostrovitých krystalů hematitu (bílé), vzorek STR-4. Všechny snímky Z. Dolníček. 


\section{Charakteristika strusek a železa}

Blíže studovány byly čtyři vzorky. Tři z nich (STR-1, $-2,-3)$ jsou tvořeny struskou, poslední vzorek (STR-4) reprezentuje fragment vyredukovaného železa (obr. 2). Vzorky strusek dosahují velikosti až $7 \times 12 \mathrm{~cm}$ (obr. 2a-c). Ve všech případech jde o úlomky větších kusů; na některých vzorcích je zachovaný původní silně nerovný povrch. Na povrchu i čerstvém lomu jsou všechny strusky černé, sklovitého vzhledu, skelně lesklé či matné. Ojediněle jsou ve struskách prítomny malé světlejší domény špinavě bílozelené barvy (obr. 2a,c). Na povrchu mají strusky často připečená křemenná zrna (obr. 2b). Všechny strusky maji lasturnatý lom a v tenkých třískách špinavě zeleně prosvítají. Jsou také silně porézní - porozita je z větší části způsobena hojnými okrouhlými bublinami variabilní velikosti (max. až přes $2 \mathrm{~cm}$ ), v menší míře i uzavřeninami dřevěného uhlí (velikost až $2 \mathrm{~cm}$; vzorky STR-1, -2), které je ve vzorcích zčásti dochované (obr. $2 b$ ), místy vyhořelé. Vzorky strusek relativně slabě reagují na feritový magnet, jenž je vzorky strusek místy slabě pritahován, ale sám na vzorcích „nedrží“. Vzorek železa (STR-4; obr. 2d) má velikost $7 \times 5 \mathrm{~cm}$ a hmotnost kolem $0.5 \mathrm{~kg}$. Jeho povrch je značně nerovný, prostoupený struskou a slabě rezavý (obr. 2d). Na řezu je kov železně šedý, homogenní, jen s malým obsahem makroskopicky patrných struskových vměstků.

Podrobnější mikroskopické studium nábrusů ukázalo, že fázové složení strusek je ve všech čtyřech vzorcích velmi jednoduché. Většina objemu strusek je tvořena sklovinou, která jen lokálně obsahuje krystaly složením blízké fayalitu, dále železo, neroztavené relikty křemene a zcela ojediněle i hematit. Struktura strusek je tedy převážně sklovitá, jen místy hemikrystalická.

Sklovina je zcela převažující fází ve všech studovaných vzorcích strusek. V BSE obraze je charakteristicky patrná její nehomogenní stavba (obr. 3a,b). Časté jsou fluidální textury, vzniklé tečením roztaveného materiálu, dobře viditelné díky rozdílům $v$ chemickém složení jednotlivých proužků skloviny (obr. 3a). Velmi charakteristické jsou také tmavší ( $v$ obraze BSE) lemy kolem korodovaných zrn křemene, tvořené sklovinou s vyšším obsahem $\mathrm{SiO}_{2}$ (obr. 3b). I při velkém zvětšení je sklovina většinou homogenní, nedevitrifikovaná, lokálně s obsahem mik- roskopických kulovitých kapiček vyredukovaného kovu. Devitrifikace skla byla pozorována pouze v lemech kolem partií obsahujících krystalickou silikátovou fázi blízkou fayalitu (obr. 3c-d).

Podrobně bylo studováno chemické složení skloviny. Celkem bylo pořízeno 54 bodových WDS analýz ze všech čtyř studovaných vzorků. Reprezentativní výběr analýz je uveden $v$ tabulce 1 a graficky jsou variace $v$ chemismu skloviny ilustrovány na obrázku 4. Chemické složení je značně proměnlivé, a to jak $v$ rámci jednoho kusu strusky, tak i u různých vzorků. Obsahy $\mathrm{SiO}_{2}$ se pohybují mezi 37.0 a 77.3 hm. \%, FeO 3.9 - 48.7 hm. \%, $\mathrm{Al}_{2} \mathrm{O}_{3} 2.2$ - 9.7 hm. \%, $\mathrm{CaO} 0.4-10.8$ hm. \%, MgO $0.1-3.5$ hm. \%, MnO $0.7-10.7 \mathrm{hm} . \%, \mathrm{Na}_{2} \mathrm{O} 0.3-1.1 \mathrm{hm} . \%, \mathrm{~K}_{2} \mathrm{O} 1.1-6.3 \mathrm{hm}$. $\%, \mathrm{P}_{2} \mathrm{O}_{5} 0.0-1.1 \mathrm{hm}$. \%, $\mathrm{TiO}_{2} 0.0-0.8 \mathrm{hm}$. \%, $\mathrm{SO}_{3} 0.0-$ $1.0 \mathrm{hm}$. \%. Obsahy $\mathrm{BaO}$ a $\mathrm{ZrO}_{2}$ nepřesahují $0.3 \mathrm{hm}$. \%. $\checkmark$ př́padě $\mathrm{Fe}, \mathrm{Mg}$ a $\mathrm{Mn}$ můžeme pro většinu dat konstatovat zřetelný nepřímo úměrný vztah vůči obsahům $\mathrm{SiO}_{2}$ (obr. 4a,b,f), v př́ipadě Mn navíc komplikovaný přitomností dvou subparalelně orientovaných datových polí (obr. 4b). V prípadě alkálií, Ca a Al Ize pozorovat až do hodnoty cca $50 \% \mathrm{SiO}_{2}$ prrímo úměrný vztah, nahrazený pro vyšší obsahy $\mathrm{SiO}_{2}$ vztahem neprímo úměrným (obr. 4c-e).

Fayalit je jedinou silikátovou krystalickou fází v ojedinělých hemikrystalických partiích studovaných strusek. Fayalit obsahující partie jsou charakteristicky prítomny pouze při vnějším okraji struskových kusů (obr. 3c) a makroskopicky se vyznačují mléčným zakalením a špinavě bílozelenou barvou (obr. 2c). Tyto domény mají velikost do $5 \mathrm{~mm}$ a charakteristickou zonální stavbu. Největší a nejlépe vyvinuté krystaly fayalitu jsou prítomny na okraji vzorku, zatímco směrem do centra struskového slitku jsou jeho krystaly čím dál více jemnější, až přecházejí $\checkmark$ devitrifikované sklo (obr. $3 c$ ). Ve stejném směru na BSE snímcích klesá i fázový kontrast mezi krystalickou fází a sklem, v důsledku stírání rozdílů v chemismu obou fází. Fayalit vytvárí kostrovité krystaly lištovitého tvaru o maximální velikosti až $0.5 \mathrm{~mm}$. Z hlavní lišty běžně dendriticky rostou jemná mladší individua, za vzniku charakteristických peřičkovitých textur (obr. 3c). Typickým jevem je též př́tomnost hojných inkluzí skla v krystalech fayalitu.

Většina naměřených bodových WDS analýz se více či méně odchyluje od ideální stechiometrie olivínu. Nej-

Tabulka 1 Př́klady chemického složení skloviny. Obsahy oxidů v hm. \%

\begin{tabular}{|c|c|c|c|c|c|c|c|c|c|c|c|c|c|c|}
\hline An. č. & 1 & 2 & 3 & 4 & 5 & 6 & 7 & 8 & 9 & 10 & 11 & 12 & 13 & 1 \\
\hline Vzorek & STR-1 & STR-3 & STR-4 & STR-2 & STR-3 & STR-1 & STR-4 & STR-1 & STR-1 & STR-3 & STR-4 & STR-4 & STR-3 & STR-1 \\
\hline $\mathrm{O}_{3}$ & 0 & 0 & 0.36 & 011 & 030 & 10 & 056 & 0.19 & & 012 & 000 & 0.11 & 0 & \\
\hline $\mathrm{O}_{5}$ & 0.41 & 0.26 & 0.97 & 0.57 & 0.50 & 0.57 & 0.73 & 0 & 0.09 & 0 & 0 & & 0 & 0.11 \\
\hline $\mathrm{O}_{2}$ & 0 & 0.08 & 0 & 0.26 & 0.22 & 0.31 & 0.35 & 0.25 & 0.33 & 0.33 & 0.23 & 0.21 & 0.09 & 0.13 \\
\hline $\mathrm{iO}_{2}$ & 37.04 & 39.18 & 40.69 & 43.53 & 48.93 & 49.07 & 51.82 & 53.03 & 58.66 & 61.68 & 68.40 & 68.92 & 76.03 & 77.34 \\
\hline $\mathrm{rO}_{2}$ & 0 & 11 & 0 & 0 & 0 & 0 & .11 & 0 & 0 & 0 & 0 & 0 & 0.29 & \\
\hline $\mathrm{I}_{2} \mathrm{O}_{3}$ & 2.73 & 3.44 & 4.96 & 5.35 & 5.45 & 7.19 & 6.66 & 6.21 & 7.62 & 5.63 & 8.88 & 8.79 & 3.83 & 5.11 \\
\hline $\mathrm{gO}$ & & 1.50 & 3.47 & 0.89 & 0.68 & 0.38 & 2.68 & 0.95 & & 1.21 & 1.25 & & 0.50 & 0.19 \\
\hline $\mathrm{aO}$ & & & & 2.45 & 3.84 & 3.41 & 10.41 & 2.87 & 1.57 & 3.20 & & & 1.20 & 0.43 \\
\hline $\mathrm{aO}$ & 0 & 0 & 0.23 & 0 & 0 & 0 & 0 & 0 & 0 & 0.10 & 0.1 & 0.1 & 0.10 & \\
\hline InO & 43 & & 8.48 & 10 & 63 & 48 & 66 & .58 & .37 & 10.67 & 3.36 & 2.76 & 2.25 & 0.70 \\
\hline $\mathrm{eO}$ & 7.20 & 5.90 & 29.71 & 38.47 & 32.56 & 31.72 & 15.23 & 26.63 & 22.29 & 11.64 & 3.89 & 5.03 & 10.42 & 12.44 \\
\hline $\mathrm{a}_{2} \mathrm{O}$ & .29 & 74 & 51 & 0.99 & 0.59 & 1.07 & 64 & 0.44 & 0.96 & 0.70 & 0.79 & 0.64 & 0.86 & 0.76 \\
\hline${ }_{2} \mathrm{O}$ & 1.26 & 1.51 & 3.18 & 1.79 & 2.04 & 2.42 & 3.99 & 2.98 & 3.33 & 2.74 & 5.61 & 6.32 & 3.92 & 3.12 \\
\hline elke & 97.62 & 99.18 & 98.70 & 99.54 & 99.74 & 100.81 & 98.84 & 99.13 & 100.14 & 98.02 & 97.04 & 97.66 & 99.49 & 100.33 \\
\hline
\end{tabular}



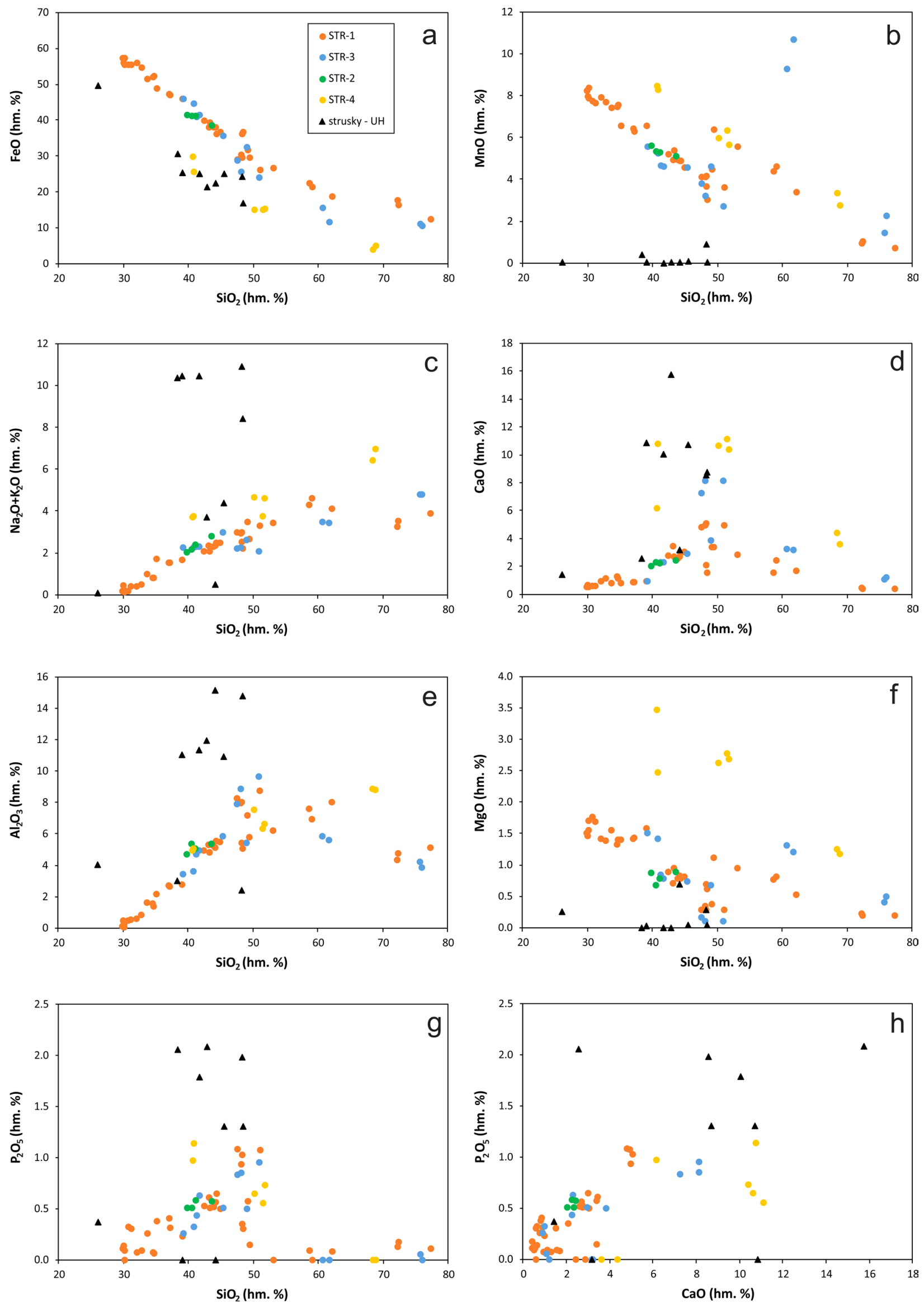

Obr. 4 Variace v chemickém složení skloviny v porovnání se složením skloviny historických železářských strusek Uherskohradišt'ska (srovnávací data převzata z Křivánka 2009, 2015). a - diagram $\mathrm{SiO}_{2}$ - FeO; b - diagram $\mathrm{SiO}_{2}-\mathrm{MnO}_{3}$; c - diagram $\mathrm{SiO}_{2}-\mathrm{Na}_{2} \mathrm{O}+\mathrm{K}_{2} \mathrm{O}$; d - diagram $\mathrm{SiO}_{2}$ - CaO; e - diagram $\mathrm{SiO}_{2}-\mathrm{Al}_{2} \mathrm{O}_{3} ;$ - diagram $\mathrm{SiO}_{2}$ - $\mathrm{MgO}$; $g$ - diagram $\mathrm{SiO}_{2}-\mathrm{P}_{2} \mathrm{O}_{5} ; h$ - diagram $\mathrm{CaO}-\mathrm{P}_{2} \mathrm{O}_{5}$. 
lepší výsledek poskytly největší krystaly fayalitu z okraje vzorků (tab. 2), i u nich Ize ale konstatovat mírný přebytek prvků v pozici Si (min. 1.016 apfu) a sníženou hodnotu Catsum (max. 1.969 apfu), což je bud' důsledkem špatné krystaličnosti dané fáze a/nebo př́tomnosti skelných mikroinkluzí. S takovou interpretací jsou v souladu i zvýšené obsahy $\mathrm{Al}$ a v řadě príípadů i $\mathrm{Na}, \mathrm{K}$ a Ti, které by $\mathrm{v}$ olivínu neměly být př́tomny. Z analýz je nicméně zřejmé, že jde o olivín a nikoliv napríklad o pyroxen. Daná fáze je poměrně chemicky homogenní, obsahuje 82.4 - 83.0 mol. \% fayalitu, 11.6 - 12.2 mol. \% tefroitu, 3.7 - 4.7 mol. \% forsteritu a 0.9 - 1.8 mol. \% dikalciumsilikátu (tab. 2, obr. 5). Analýzy z ostatních prítomných morfologických forem fayalitu jsou i při použití minimální možné šířky elektronového svazku $(0.7 \mu \mathrm{m})$ vždy silně kontaminovány sklem.

Hematit byl zjištěn zcela ojediněle $v$ podobě shluku několika drobných (max. $20 \mu \mathrm{m}$ velkých) dendritických krystalů, uzavřených ve skle (obr. 3d). Jeho chemické složení (tab. 2) se vyznačuje zvýšenými obsahy $\mathrm{Si}, \mathrm{Al}, \mathrm{Ti}$, Mg, Ca a Mn (0.007 - 0.087 apfu).

Železo je jednak prítomno $v$ podobě kulatých kapek (o průměru max. $0.2 \mathrm{~mm}$ ), náhodně uzavíraných ve strus- ce (vzorky STR1, -2, -3), jednak je hlavní součástí železné houby (vzorek STR-4). Jak v odrazovém mikroskopu, tak na BSE snímcích je patrná kompozičně nehomogenní vnitřní stavba kovu, která má odlišný charakter v malých kapkách a v železné houbě. Jak ukázaly mikrosondové analýzy, hlavním prvkem, který je přičinou pozorované texturní nehomogenity, je fosfor. Fosforem bohaté partie maji v odrazovém mikroskopu nažloutlou barvu a v BSE obraze tmavší odstín v porovnání s čistým železem, které je $v$ odraženém světle bílé a $v$ obraze BSE světlé (obr. 6a-c). Pro drobné kapky kovu uzavřené ve strusce (obr. 6a) je charakteristická přítomnost okrouhlých až polygonálních individuí nízkofosforového železa ( $\mathrm{s}$ obsahem $\mathrm{P}$ mezi 0.4 - $1.9 \mathrm{hm}$. \%), které jsou uzavřené $v$ matrici se zvýšeným obsahem fosforu (3.1 - 10.3 hm. \% P). Kvantitativní zastoupení obou složek je proměnlivé, $v$ různých kapkách se podíl fosforem bohaté matrice pohybuje mezi cca 20 a 40 obj. \%. Proměnlivý je v důsledku toho i celkový obsah fosforu $v$ jednotlivých kapkách, který kolísá mezi 0.9 a $5.1 \mathrm{hm}$. \%. Naproti tomu železná houba vykazuje např́č vzorkem kontinuální změnu textury. Na jedné straně Ize pozorovat situaci, kdy jsou kostrovitě

Tabulka 2 Chemické složení fayalitu (Fa) a hematitu (Hem) ze studovaných strusek. Obsahy oxidů v hm. \%, hodnoty apfu jsou vypočitány na základ 4 (fayalit), resp. 3 (hematit) atomů kyslíku. Obsahy koncových členů v mol. \%. DCS - dikalciumsilikát

\begin{tabular}{|c|c|c|c|c|c|c|c|c|c|c|}
\hline An. č. & 1 & 2 & 3 & 4 & 5 & 6 & 7 & 8 & 9 & 10 \\
\hline Fáze & $\mathrm{Fa}$ & $\mathrm{Fa}$ & $\mathrm{Fa}$ & $\mathrm{Fa}$ & $\mathrm{Fa}$ & $\mathrm{Fa}$ & $\mathrm{Fa}$ & Hem & Hem & Hem \\
\hline Vzorek & STR-1 & STR-1 & STR-1 & STR-1 & STR-1 & STR-1 & STR-1 & STR-4 & STR-4 & STR-4 \\
\hline $\mathrm{P}_{2} \mathrm{O}_{5}$ & 0.11 & 0.31 & 0.33 & 0.07 & 0.09 & 0.14 & 0 & & & \\
\hline $\mathrm{TiO}_{2}$ & 0 & 0.08 & 0 & 0 & 0 & 0 & 0.08 & 0.37 & 0.35 & 0.38 \\
\hline $\mathrm{SiO}_{2}$ & 30.51 & 31.84 & 31.41 & 30.65 & 30.78 & 30.85 & 31.04 & 1.95 & 2.11 & 2.73 \\
\hline $\mathrm{Al}_{2} \mathrm{O}_{3}$ & 0.12 & 0.53 & 0.51 & 0.58 & 0.05 & 0.48 & 0.26 & 2.88 & 2.72 & 2.77 \\
\hline $\mathrm{Fe}_{2} \mathrm{O}_{3}$ & & & & & & & & 91.47 & 91.34 & 90.39 \\
\hline $\mathrm{FeO}$ & 58.28 & 56.44 & 56.40 & 56.97 & 58.47 & 57.55 & 57.17 & & & \\
\hline $\mathrm{MnO}$ & 8.39 & 7.78 & 7.87 & 8.08 & 8.56 & 8.19 & 8.10 & 2.52 & 2.47 & 2.35 \\
\hline $\mathrm{MgO}$ & 1.54 & 1.72 & 1.81 & 1.45 & 1.73 & 1.50 & 1.60 & 0.74 & 0.83 & 0.72 \\
\hline $\mathrm{CaO}$ & 0.55 & 0.60 & 0.64 & 0.96 & 0.52 & 0.68 & 0.63 & 0.61 & 0.79 & 0.91 \\
\hline $\mathrm{BaO}$ & 0.20 & 0 & 0.16 & 0 & 0.16 & 0 & 0 & & & \\
\hline $\mathrm{Na}_{2} \mathrm{O}$ & 0.17 & 0.11 & 0 & 0.16 & 0.11 & 0.19 & 0.11 & & & \\
\hline$\underline{\mathrm{K}_{2} \mathrm{O}}$ & 0 & 0.28 & 0.19 & 0.23 & 0 & 0.26 & 0.13 & & & \\
\hline Celkem & 99.89 & 99.69 & 99.32 & 99.15 & 100.48 & 99.84 & 99.12 & 100.54 & 100.61 & 100.25 \\
\hline $\mathrm{P}^{5+}$ & 0.003 & 0.008 & 0.009 & 0.002 & 0.003 & 0.004 & 0 & & & \\
\hline $\mathrm{Ti}^{4+}$ & 0 & 0.002 & 0 & 0 & 0 & 0 & 0.002 & 0.007 & 0.007 & 0.007 \\
\hline $\mathrm{Si}^{4+}$ & 1.013 & 1.038 & 1.031 & 1.018 & 1.015 & 1.018 & 1.030 & 0.050 & 0.054 & 0.070 \\
\hline $\mathrm{Al}^{3+}$ & 0.005 & 0.020 & 0.020 & 0.023 & 0.002 & 0.019 & 0.010 & 0.087 & 0.082 & 0.084 \\
\hline $\mathrm{Fe}$ & 1.619 & 1.539 & 1.549 & 1.582 & 1.612 & 1.588 & 1.586 & 1.770 & 1.765 & 1.744 \\
\hline $\mathrm{Mn}^{2+}$ & 0.236 & 0.215 & 0.219 & 0.227 & 0.239 & 0.229 & 0.227 & 0.055 & 0.054 & 0.051 \\
\hline $\mathrm{Mg}^{2+}$ & 0.076 & 0.084 & 0.088 & 0.072 & 0.085 & 0.074 & 0.079 & 0.028 & 0.032 & 0.028 \\
\hline $\mathrm{Ca}^{2+}$ & 0.020 & 0.021 & 0.023 & 0.034 & 0.018 & 0.024 & 0.022 & 0.017 & 0.022 & 0.025 \\
\hline $\mathrm{Ba}^{2+}$ & 0.003 & 0 & 0.002 & 0 & 0.002 & 0 & 0 & & & \\
\hline $\mathrm{Na}^{+}$ & 0.011 & 0.007 & 0 & 0.011 & 0.007 & 0.012 & 0.007 & & & \\
\hline $\mathrm{K}^{+}$ & 0 & 0.011 & 0.008 & 0.010 & 0 & 0.011 & 0.006 & & & \\
\hline Catsum & 2.985 & 2.946 & 2.949 & 2.978 & 2.984 & 2.978 & 2.970 & 2.014 & 2.015 & 2.009 \\
\hline $\mathrm{Fa}$ & 83.0 & 82.8 & 82.4 & 82.6 & 82.5 & 82.9 & 82.8 & & & \\
\hline Fo & 3.9 & 4.5 & 4.7 & 3.7 & 4.4 & 3.9 & 4.1 & & & \\
\hline DCS & 1.0 & 1.1 & 1.2 & 1.8 & 0.9 & 1.3 & 1.2 & & & \\
\hline $\mathrm{Te}$ & 12.1 & 11.6 & 11.7 & 11.9 & 12.2 & 12.0 & 11.9 & & & \\
\hline
\end{tabular}


rostlé dendrity nízkofosforového železa $(0.3-0.7 \mathrm{hm}$. \% P) uzavírány $v$ kvasihomogenní fosforem bohatší matrici (s max. 10.5 hm. \% P; obr. 6b). Postupujeme-li směrem k opačnému konci vzorku, můžeme pozorovat, že postup- ně ubývá reliktů nízkofosforového železa a zvětšuje se podíl základní matrice, která se však začíná diferencovat v jednotlivá dlažbovitě upořádaná zrna kovu, vzájemně se mírně lišící obsahem $\mathrm{P}$ (obr. 6b nahoře). Na opačném
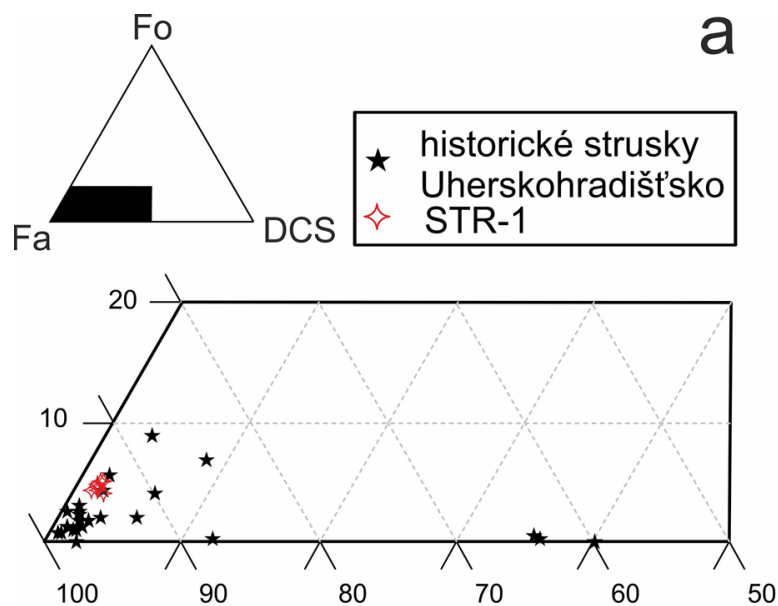
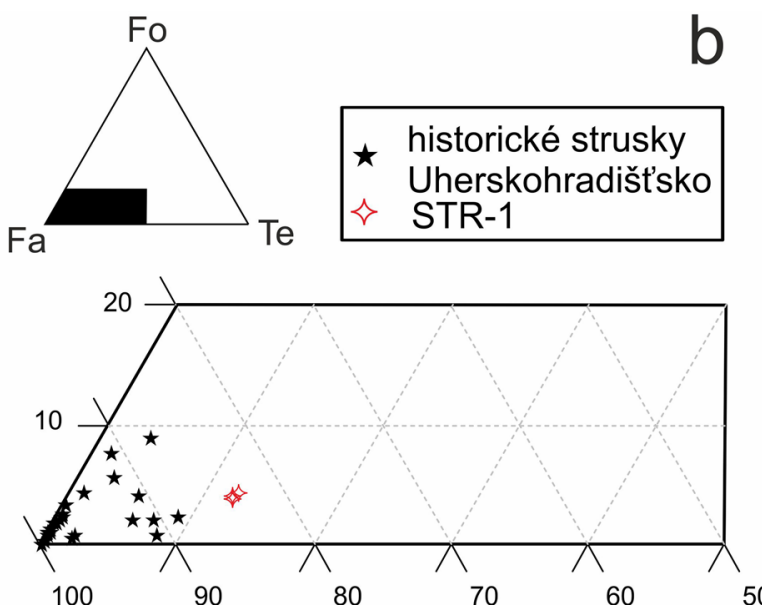

Obr. 5 Projekce chemického složení olivínu v diagramu fayalit-forsterit-dikalciumsilikát (a) a v diagramu fayalit-forsterittefroit (b). Srovnávaci data z historických železářských strusek Uherskohradišt’ska jsou převzata z Křivánka (2009, 2015).
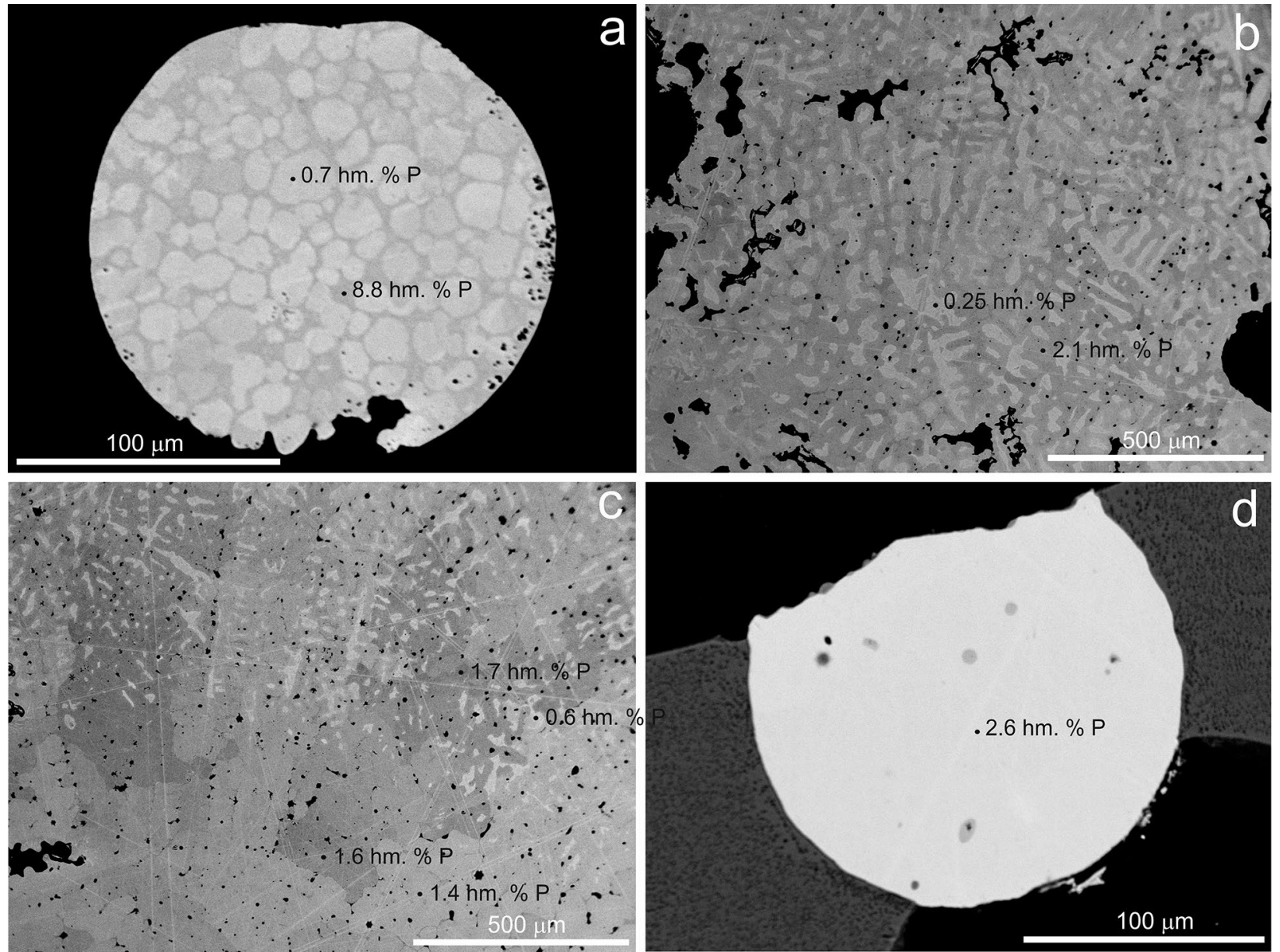

Obr. 6 Vnitřní stavba a fázové složení vyredukovaného kovu na BSE snímcích. a - izometrická individua nízkofosforového železa obklopená matricí s vysokým obsahem fosforu v železné kapce ze vzorku STR-2. b - krystalograficky orientované vyloučeniny nízkofosforového železa uzavřené v kvasihomogenní fosforem bohatší kovové matrici železného slitku vzorku STR-4. c - rozhraní dvou texturně odlišných domén v železném slitku vzorku STR-4. Nahoře jsou ještě přitomny relikty krystalograficky orientovaných vyloučenin nízkofosforového železa, uložených v rekrystalované fosforem bohatši matrici, zatímco ve spodní části snímku jsou již relikty nízkofosforového železa $v$ důsledku pokročilé rekrystalizace kovu zcela resorbovány. $d$ - drobné okrouhlé inkluze pyrhotinu, uzavírané v kovové matrici železné kapky ze vzorku STR-1. Všechny snímky Z. Dolníček. 
konci vzorku pak pozorujeme dlažební texturu zrn železa (obr. 6b dole) $\mathrm{s}$ jen mírně variabilními průměrnými obsahy fosforu (1.4 - $1.6 \mathrm{hm}$. \% P). Vedle Fe a P byly mikrosondovými analýzami (tab. 3 ) zaznamenány ještě príměsi $\mathrm{Ni}$ (max. $0.16 \mathrm{hm} . \%)$, Co (max. $0.09 \mathrm{hm}$. \%) a v některých př́padech i dosti zvýšené obsahy síry (až $0.69 \mathrm{hm}$. \%), která však byla měřena jen u malého počtu analýz. Zhruba třetina získaných analýz má snížené analytické sumy (95 - 98 hm. \%), které by mohly nasvědčovat přitomnosti zvýšené koncentrace uhlíku. Tyto nižší sumy analýz byly zjištěny zejména v některých kovových kapkách ve vzorcích STR-2 a -3, naproti tomu ve vzorcích STR-1 a -4 se téměř nevyskytly.

Pyrhotin vytváří drobné sférické útvary o průměru maximálně $10 \mu \mathrm{m}$, uzavírané porůznu $v$ kovovém železe ( $v$ kapkách i v houbě; obr. $6 \mathrm{~d}$ ). $V$ odraženém světle má bronzovou barvu a při zkřižených nikolech je znatelně anizotropní. Chemické složení bylo ověřeno analýzami na mikrosondě (tab. 3). Vedle železa a síry byly zjištěny i zvýšené obsahy Mn (0.05 - 0.40 hm. \%), P (0.06 - 0.61 hm. \%), Pb (max. 0.14 hm. \%), Cu (max. 0.13 hm. \%), Co $(\max .0 .06 \mathrm{hm} . \%)$ a Ni $(\max .0 .05 \mathrm{hm} . \%)$.

\section{Diskuse}

Záměrem této práce bylo zkoumat strusky jen z tavby, při níž byla použita místní ruda, s časovým odstupem ovšem vznikla nejistota, jestli vzorky předané $\mathrm{k}$ analýze jsou skutečně jen z této tavby. Provedené analytické práce jednoznačně potvrzují, že studované strusky skutečně pocházejí z tavby, při níž bylo použito místní železné rudy a ne z tavby, při níž bylo užito indického hematitu. Zvýšené obsahy $\mathrm{Ca}, \mathrm{Mg}$ a $\mathrm{Mn}$ jsou pro zdejší pelosideritové rudy charakteristické (Burkart 1953; Krut’a 1966; Křivánek 2015; Dolníček et al. 2019). Vedle karbonátů a detritické př́měsi (tvořené zejména křemenem a jílovými minerály) byly $v$ akcesorickém množství $v$ pelosideritech zjištěny $i$ sulfidy $\mathrm{Fe}$ a $\mathrm{Cu}$ (pyrit a chalkopyrit), v nichž byly zjištěny příměsi $\mathrm{Ni}, \mathrm{Co}, \mathrm{Pb}, \mathrm{Mn}$ a Hg (Dolníček et al. 2019). S výjimkou rtuti, která je za vysokých teplot extrémně těkavá, byly všechny zmíněné kovy detekovány jako příměsi ve vyredukovaném železe či v pyrhotinu. Zajímavá je př́tomnost zvýšených koncentrací fosforu, který ve starších analýzách Fe-rud nebyl stanovován (srov. Burkart 1953). Křivánek (2015) však uvádí ve vzorku limonitu ze Strážovského vrchu $0.75 \mathrm{hm}$. $\% \mathrm{P}_{2} \mathrm{O}_{5}$. Nově Dolníček et al. (2019) nalezli v asociaci s pelosiderity i fosforitovou konkreci a Dolníček et al. (2020) dokonce z Chřibů popisuji směsnou konkreci, tvořenou apatitem a Mn-Fe karbonáty. $Z$ uvedeného je patrné, že i zvýšené koncentrace $P$ ve skle a ve vyredukovaném kovu rovněž dobře odrážeji chemické složení místní nerostné suroviny.

Technolity studované $v$ této práci byly vyrobeny $\mathrm{v}$ replice šachtové pece, pracující tzv. prímou metodou. Srovnáme-li zjištěné fázové složení s typickými železářskými struskami, vzniklými při prímé výrobě železa, musíme konstatovat výrazné rozdíly. Námi studované strusky jsou tvořeny de facto pouze sklem, zatímco $v$ typických železářských struskách jsou hlavními složkami fayalit a wüstit, kdežto sklo, pokud je vůbec přítomno, bývá jen vedlejší komponentou (Bachman 1982; Pleiner 2000; Zmeškalová 2010; Svoboda 2014; Křivánek 2015). V asociaci s typickými (hemi)krystalickými železářskými struskami bývají někdy na archeologických lokalitách v malém množství nalézány i sklovité strusky. Ty se však výrazně odlišují i chemickým složením, které je dovoluje interpretovat jako roztavený konstrukční materiál pece (srov. Zmeškalová 2010; Dolníček, Čudrnáková 2014; Křivánek 2015). To ovšem není náš prípad - šamotová hlína, použitá $\mathrm{k}$ výrobě pece, je běžně použitelná do teplot $1500{ }^{\circ} \mathrm{C}$ a má bod tání kolem $1800{ }^{\circ} \mathrm{C}$ (Dykyj ed. 1953). Ani chemické složení skloviny nenasvědčuje výraznější kontaminaci hliníkem ze šamotu (obr. 4e). V neposlední řadě skelná fáze $v$ našem případě tvoří nejen volné kusy strusek (které potenciálně mohou pocházet $z$ otavených stěn pece), ale

Tabulka 3 Př́klady chemického složení pyrhotinu (Po) a kovového železa (Fe) ze studovaných strusek. Obsahy prvků $v \mathrm{hm} . \%$, hodnoty apfu jsou vypočitány na základ 1 aniontu (pyrhotin), resp. 1 apfu (železo)

\begin{tabular}{|c|c|c|c|c|c|c|c|c|c|c|c|c|c|c|}
\hline An. č. & 1 & 2 & 3 & 4 & 5 & 6 & 7 & 8 & 9 & 10 & 11 & 12 & 13 & 14 \\
\hline Fáze & Po & Po & Po & Po & Po & $\mathrm{Fe}$ & $\mathrm{Fe}$ & $\mathrm{Fe}$ & $\mathrm{Fe}$ & $\mathrm{Fe}$ & $\mathrm{Fe}$ & $\mathrm{Fe}$ & $\mathrm{Fe}$ & $\mathrm{Fe}$ \\
\hline Vzorek & STR-4 & STR-4 & STR-4 & STR-4 & STR-4 & STR-4 & STR-3 & STR-2 & STR-3 & STR-3 & STR-4 & STR-4 & STR-4 & STR-4 \\
\hline $\mathrm{Fe}$ & 62.76 & 62.71 & 63.25 & 63.31 & 63.43 & 88.76 & 88.53 & 85.87 & 87.88 & 91.67 & 96.99 & 97.29 & 98.61 & 98.39 \\
\hline Co & 0.04 & .04 & 0.04 & 0.06 & 0.05 & 0.09 & 0.07 & 0 & 0 & 0.07 & 0 & 0 & 0.07 & 0 \\
\hline & 0 & .05 & 0 & 0 & 0.04 & 0.16 & 0.09 & 0.22 & 0.11 & 0.18 & 0.11 & 0.11 & 0.09 & \\
\hline Mn & 0.31 & & 0.28 & 0.36 & 0.31 & 0 & 0 & 0 & 0 & 0 & 0 & $\Omega$ & 0 & 0 \\
\hline $\mathrm{Cu}$ & 0.13 & 13 & .13 & 0.12 & 0.11 & & & & & & & & & \\
\hline $\mathrm{b}$ & 0.10 & 0.13 & 0.10 & 0.13 & 0.09 & & & & & & & & & \\
\hline$S$ & 35.92 & 35.99 & 35.85 & 35.87 & 36.09 & 0.64 & 0.69 & & & 0.34 & & & 0 & \\
\hline & 0.19 & .04 & 0.10 & 0.33 & 0.61 & 10.46 & 9.53 & 8.84 & 7.40 & 3.89 & 2.12 & 1.85 & 0.60 & 0.26 \\
\hline Celkem & 99.45 & 99.27 & 99.75 & 100.18 & 100.73 & 100.11 & 98.91 & 95.66 & 95.95 & 96.15 & 99.41 & 99.43 & 99.37 & 98.72 \\
\hline e & 998 & .999 & 1.010 & 004 & 92 & 0.814 & 0.827 & 0.842 & 0.867 & 0.9 & 0.961 & 0.966 & 0.988 & 0.995 \\
\hline o & 0.001 & 0.001 & 0.001 & 0.001 & & 0.001 & 0.001 & 0 & 0 & & 0 & 0 & 001 & 0 \\
\hline & 0 & 0.001 & 0 & 0 & 0.001 & 0.001 & 0.001 & 0.002 & 0.001 & 0.002 & 0.001 & 0.001 & 0.001 & \\
\hline $\mathrm{Mn}$ & .005 & 0.003 & 0.005 & 0.006 & 0.005 & 0 & 0 & 0 & 0 & 0 & 0 & 0 & 0 & \\
\hline $\mathrm{Cu}$ & 0.002 & 0.002 & 0.002 & 0.002 & 0.002 & 0 & 0 & 0 & 0 & 0 & 0 & 0 & 0 & 0 \\
\hline $\mathrm{Pb}$ & 0.000 & 0.001 & 0.000 & 0.001 & 0.000 & 0 & 0 & 0 & 0 & 0 & 0 & 0 & 0 & 0 \\
\hline Catsum & 1.005 & 1.006 & 1.017 & 1.013 & 1.000 & 0.817 & 0.828 & 0.844 & 0.868 & 0.924 & 0.962 & 0.967 & 0.989 & 0.995 \\
\hline & 0.995 & 0.999 & 0.997 & 0.991 & 0.983 & 0.010 & 0.011 & 0 & 0 & 0.006 & 0 & 0 & 0 & 0 \\
\hline & 0.005 & 0.001 & 0.003 & 0.009 & 0.017 & 0.173 & 0.161 & 0.156 & 0.132 & 0.070 & 0.038 & 0.033 & 0.011 & 0.005 \\
\hline
\end{tabular}


prokazatelně reprezentuje i nístějovou strusku obklopující vyredukovanou železnou houbu. Důvodů, proč silikátová tavenina nevykrystalizovala, může být několik:

Za prvé můžeme předpokládat nevhodnou viskozitu taveniny. Je-li její viskozita přiliš vysoká, proces krystalizace je brzděn přiliš pomalým přísunem stavebních částic (atomů, iontů, molekul) k rostoucímu krystalu. Viskozita je úměrná teplotě a chemickému složení taveniny. Obecně viskozita roste s klesající teplotou a s rostoucím obsahem $\mathrm{SiO}_{2}$. Bachman (1982) počítá z chemického složení strusek tzv. index viskozity (v.i.), jehož hodnota se pro strusky ze světových lokalit nejčastěji pohybuje mezi 0.5 a 1.0. Hodnoty v.i. se pro námi analyzovanou sklovinu pohybuji ve velmi širokém intervalu mezi 0.21 a 1.44 ; průměrná hodnota je 0.81 . $Z$ toho je patrné, že ačkoliv jsou ve strusce nepochybně prítomny oblasti s vysloveně „viskózním“ složením, většina námi analyzovaných složení z tohoto pohledu nevybočuje z průměru.

Druhým možným vysvětlením může být nevhodný teplotní režim při tavbě, jmenovitě kombinace prriliš vysoké teploty a následného prudkého ochlazení. $V$ železářských pecích pro prímou redukci je v nístěji obvykle dosahováno teplot $900-1300{ }^{\circ} \mathrm{C}$ (Pleiner 2000; Stránský et al. 2000), výjimečně i přes $1400{ }^{\circ} \mathrm{C}$ (Pleiner 2000). $\mathrm{K}$ odhadu dosažené teploty je možné využít například chemického složení taveniny, pokud ho Ize aproximovat experimentálně proměřeným systémem. $V$ našem př́ipadě je chemické složení silikátové taveniny př́liš složité. Vhodným kandidátem pro posouzení teplotního režimu se však jeví vyredukovaná kovová fáze. Dokonale kulovitý tvar kovových kapek uzavíraných ve strusce (obr. 3a, 6a) jasně ukazuje, že kov byl původně v tekutém stavu. Navíc kovové kapky obsahují drobné, opět dokonale kulovité kapky pyrhotinu (obr. 6d), jejichž vznik Ize vysvětlit jedině odmíšením sulfidické taveniny $v$ kapalné fázi. Pomineme-li nehojné prípady, kdy nelze vyloučit přitomnost vyšších koncentrací uhlíku, můžeme chemické složení kovové fáze velmi dobře aproximovat systémem Fe-P (obr. 7). Stanovenému minimálnímu zjištěnému obsahu $P$ v celé kovové kapce (cca $1 \mathrm{hm}$. \%) odpovídá nejvyšší tep-

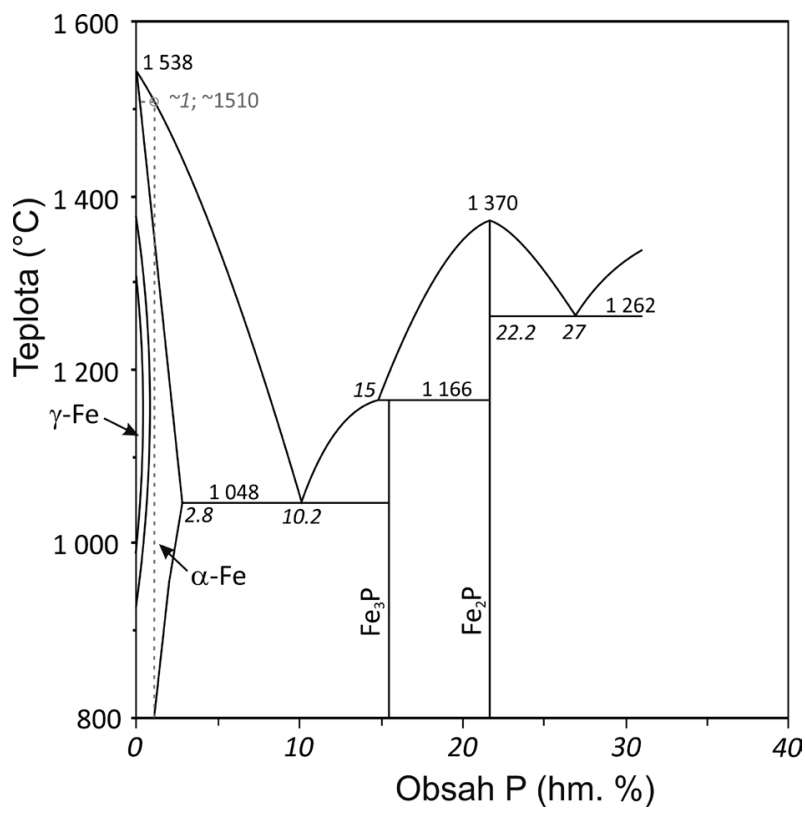

Obr. 7 Fázový diagram systému Fe-P (upraveno podle Okamota 1990) s ilustrací odvození teplot diskutovaných v textu (světle šedou barvou). lota začátku krystalizace kovové taveniny při cca $1510^{\circ} \mathrm{C}$ (obr. 7). Z původně homogenní kovové taveniny se při poklesu teploty nejprve vyloučily krystaly fosforem chudého železa, kdežto většina fosforu zůstala nakoncentrována $\checkmark$ reziduální tavenině. Reziduální tavenina se s klesající teplotou stále více obohacovala o fosfor a po dosažení eutektické teploty $\left(1048{ }^{\circ} \mathrm{C}\right.$; obr. 7$)$ by měla utuhnout $v$ jemnozrnnou směs železa a schreibersitu $\left(\mathrm{Fe}_{3} \mathrm{P}\right)$. Maximální obsah $\mathrm{P}$, stanovený $\mathrm{v}$ mezerní hmotě i při použití „nulové“ šírky elektronového svazku, dosahoval $10.5 \mathrm{hm}$. $\% \mathrm{P}$, což velmi dobře odpovídá složení eutektika systému Fe-P (10.2 hm. \%; Okamoto 1990; obr. 7). Nižší obsahy $\mathrm{P} \vee$ mezerní hmotě mohou indikovat, že proces frakční krystalizace nedoběhl až do konce, ale byl „zmražen“ prudkým zchlazením (např. $v$ důsledku otevření pece po ukončení tavby). Poněkud odlišný vývoj můžeme interpretovat z kovové fáze železné „lupy“. Minimálně část kovu byla i v tomto případě původně kapalná - jasně tomu nasvědčuji kulovité inkluze sulfidů a také dendritické vyloučeniny nízkofosforového železa sledující krystalografické směry (obr. 6b,c). Postupnou změnu textury kovu napřič vzorkem, charakterizovanou ubýváním a posléze i vymizením původních dendritů nízkofosforového železa, a spojenou $s$ rekrystalizací kovové matrice $v$ granoblastický agregát $\mathrm{s} v$ podstatě zprůměrovaným obsahem $\mathrm{P}$ (obr. 6c), můžeme vysvětlit opětovným zahřátím kovu, při němž došlo $v$ důsledku difuze $P$ za podmínek subsolidu (Rawdon 1917; Stewart et al. 2000) k opětovné homogenizaci chemismu. Uvedený jev může být např́klad důsledkem pokusu o odpuštění strusky a následného uzavření pece a pokračování v tavbě. Výše uvedená teplota nad $1500{ }^{\circ} \mathrm{C}$ je v souladu i s pravděpodobnými lokálně zvýšenými koncentracemi uhlíku v některých železných kapkách. Z uvedeného vyplývá, že dosažená maximální teplota byla pravděpodobně skutečně vyšší, než bývá obvyklé, a pokud byla kombinována s rychlým ochlazením pecního prostoru (okamžité otevření nístěje pece hned po ukončení dmýchání vzduchu a vylomení nístějového slitku), mohlo to významně přispět k zachování skelného stavu struskové hmoty.

Třetí možná přičina, proč nedošlo ke krystalizaci, může být ve specifickém chemickém složení strusky. Kapusta (2013) zjistil, že baryem bohaté strusky po hutnickém zpracování polymetalických (Ag-Pb-Zn) rud z Jihlavy obsahují prakticky jen sklovinu a pouze ojediněle i malé množství krystalů Ba-K živců, zatímco strusky bez $\mathrm{Ba}$ nebo jen s nízkým obsahem tohoto prvku byly krystalické. Je tedy možné, že zvýšený obsah Ba zde působil jako inhibitor krystalizace. V našem př́padě lze konstatovat, že jediným prvkem, jehož koncentrace vybočuje z obvyklých mezí, je mangan. Jeho obsahy jsou $v$ porovnání s typickými krystalickými železářskými struskami několikanásobně vyšší. Může-li ovšem být role daného prvku v tomto směru opravdu klíčová, bude ještě potřeba ověřit dalšími výzkumy. Zdá se však nesporné, že nějaká překážka bránící iniciální fázi nukleace byla přítomna, zatímco po jejím překonání se už proces krystalizace skelnou fází šíril zdá se vcelku bez problémů (obr. 3c). Rychlý pokles teploty (prítomnost peříčkovitých fayalitů indikuje rychlost chladnutí nad $1000{ }^{\circ} \mathrm{C} / \mathrm{h}$; Donaldson 1976) však významnější propagaci krystalizačního procesu poměrně záhy zastavil.

Absenci wüstitu ve studovaných struskách můžeme vysvětlovat bud' dokonale technologicky zvládnutým redukčním procesem nebo nízkou kovnatostí použité rudy. Častý výskyt neroztavených reliktů křemene ve strusce spolu se značným rozptylem obsahů $\mathrm{SiO}_{2}$ v chemických 
analýzách Fe-rud ze strážovického ložiska (9.4 - 58.7 hm \%; Burkart 1953, Krut’a 1966; Křivánek 2015) naznačují, že pravdě bližší bude spíše druhá možnost. Zcela ojedinělý je v námi studovaných struskách výskyt hematitu, který se $v$ typických železářských struskách nevyskytuje (srov. Svoboda 2014). Velmi neobvyklá je i morfologie tohoto hematitu (obr. 3d), která spíše upomíná na kostrovité krystaly spinelidů. Nemůžeme tedy vyloučit možnost, že jde o pseudomorfózu hematitu po magnetitu, vzniklou v oxidačních podmínkách.

Závěrem zbývá konfrontovat naše poznatky s historickými železářskými struskami z oblasti Uherskohradišt'ska. Srovnání jsme provedli se souborem strusek, který studoval J. Křivánek (Křivánek 2009, 2015) a který pokrývá významnou část období, kdy se na našem území vyrábělo železo přímou metodou - od období přelomu halštatu a laténu (5. stol. př. n. I.) až do 15. století. Z pohledu fázového složení strusek Ize konstatovat většinou zásadní rozdíl, nebot' železářské strusky mají typicky obvyklé fayalit-wüstitové složení. Jen zcela ojediněle se vyskytuji sklovité strusky, vzniklé přetavením konstrukčního materiálu pece. Značné rozdíly Ize konstatovat i v chemickém složení jednotlivých struskových fází. Fayalit i sklovina jsou ve srovnávaných železářských struskách výrazně chudší manganem (obr. $4 b$ a $5 b$ ), sklovina většinou i hořčíkem (obr. 4f). Sklovina těchto železářských strusek bývá naopak výrazněji nabohacena nekompatibilními prvky - hliníkem, alkáliemi a fosforem (obr. 4c,e,g). Kovová fáze je tvořena většinou čistým železem, ojediněle byly zaznamenány i kapky „litiny“. Fosfor nebyl u části vzorků v kovové fázi analyzován; v těchto prípadech však absence mikroskopicky patrných texturních nehomogenit, stejně jako analytické sumy blízké $100 \%$ vylučují jeho přitomnost ve vyšších koncentracích. Přítomnost sulfidů rovněž nebyla nikdy ve struskách zmiňována. $Z$ uvedeného vyplývá, že využití místních pelosideritových železných rud (a z nich zvětráváním vzniklých limonitů) nelze $\checkmark$ dané oblasti na základě provedených rozborů v období, kdy se železo vyrábělo přímou metodou, potvrdit.

\section{Závěr}

Při experimentální tavbě železa $v$ replice šachtové nadzemní pece, realizované $v$ roce 2018 na hradě Buchlově, byla použita pelosideritová a limonitová železná ruda se zvýšeným obsahem Mn z lokality Strážovice u Kyjova. Vzniklá pecní struska je prakticky výhradně tvořena jen sklovinou, jen ojedinělé malé domény obsahuji i olivín. Sklovina je kompozičně heterogenní a obsahuje 0.7 - 10.7 hm. \% MnO, olivín odpovídá fayalitu se zvýšenými obsahy tefroitové (cca $12 \mathrm{~mol}$. \%), forsteritové (cca 4 mol. \%) a dikalciumsilikátové (1 mol. \%) komponenty. Vyredukované železo je kompozičně heterogenní, bohaté fosforem a místy obsahuje drobné inkluze pyrhotinu. Fázové složení strusky se výrazně liší od typických železářských strusek. Příčinu je možné spatřovat bud' v anomálním chemickém složení vsázky (zvýšené obsahy Mn mohly působit jako inhibitor krystalizace), nebo $v$ príliš vysoké teplotě při tavbě (fázové vztahy v kovovém železe nasvědčuji teplotám nad $1500{ }^{\circ} \mathrm{C}$ ) v kombinaci s rychlým ochlazením obsahu pece po ukončení tavby. Jak fázové složení strusky, tak chemické složení struskových fází i vyredukovaného kovu se výrazně liší od charakteristik historických železářských strusek Uherskohradišt'ska z období přímé výroby železa. Uvedená zjištění tedy nepodporují domněnku, že by místní pelosideritové železné rudy mohly být již v této době využívány $\mathrm{k}$ výrobě železa.

\section{Poděkování}

Autoři děkuji oběma recenzentưm (D. Všianský a J. Kapusta) za konstruktivní pripomínky, které prispěly $k$ vylepšení rukopisu. Práce na dané problematice byly finančně podpořeny Ministerstvem kultury ČR $v$ rámci institucionálního financování dlouhodobého koncepčního rozvoje výzkumné organizace Národní muzeum (DKRVO 20192023/1.III.b, 00023272).

\section{Literatura}

BACHMANN HG (1982) The identification of slags from archaeological sites. Occasional publication No. 6, Institute of Archeology, London

BARÁK M (1995) Experimentální výroba železa v peci z doby Velké Moravy. MS, diplomová práce, VUT Brno

BURKART E (1953) Mährens Minerale und ihre Literatur. Nakl Čs Akad věd, Praha

DolNí̌EK Z, ČUdRNÁKOVÁ K (2014) Charakterizace struskových hmot z Dražůvek u Kyjova. Geol výzk Mor Slez 21: 81-84

Dolníček Z, Kandrnál L, Ulmanová J, Vratislavská E, HoJAČ P (2019) Historická těžba pelosideritů na lokalitě Koryčanská cesta u Moravan, jižní Chřiby. Bull Mineral Petrolog 27: 304-316

Dolní̌́EK Z, Kandrnál L, Ulmanová J, VRatislavská E, HoJAČ P (2020) Mineralogická charakteristika fosforitové konkrece s rodochrozitem z lokality Tabarky, severní Chřiby. Bull Mineral Petrolog 28(1): 35-43

DONALDSON CH (1976) An experimental investigation of olivine morphology. Contrib Mineral Petrol 57: 187195

DYkYJ J (ed) (1953) Fysikálně chemické tabulky I. Stát nakl tech lit, Praha

KAPUSTA J (2013) Mineralogie a chemismus strusek po tavbě stříbrných rud $z$ vybraných lokalit $v$ jihlavském rudním revíru. MS, diplomová práce, PřF UP Olomouc

KolBinger D (2011) Výzkum těžebních a zpracovatelských areálů $v$ Hostýnských vrších a jejich podhưří. Archeol Mor Slez 11: 206-219

KRUŤA T (1966) Moravské nerosty a jejich literatura (1940 - 1965). Moravské museum. Brno

KŘIVÁNEK J (2009) Inventarizace výskytů historických železářských strusek v oblasti Chřibů. MS, bakalářská práce, PřF UP Olomouc

KŘIVÁNEK J (2015) Mineralogické studium artefaktů po železářské výrobě z vybraných lokalit v okolí Starého Města u Uherského Hradiště. MS, diplomová práce, PřF UP Olomouc

Окамото H (1990) The Fe-P (iron-phosphorus) system. Bull Alloy Phase Diagr 11(4): 404-412

Pleiner R (1969) Experimental smelting of steel in early Medieval furnaces. Pam Archeol 60: 458-487

Pleiner R (2000) Iron in Archeology: The European Bloomery Smelters. Archeologický ústav AV ČR, Praha

Pouchou JL, PICHOIR F (1985) "PAP" ( $\varphi \rho Z)$ procedure for improved quantitative microanalysis. In: ARMSTRONG JT (ed.) Microbeam Analysis: 104-106. San Francisco Press, San Francisco

RAwDon HS (1917) Some unusual features in the microstructure of wrought iron. Technologic papers of the Bureau of Standards 97: 1-25

Souchopová V (1986) Hutnictví železa v 8.-11. století na západní Moravě. Stud Stát Archeol Úst ČSAV v Brně 13, 1, 109 pp, Academia Praha 
Stewart JV, Charles AJ, Wallach E (2000) Iron-phosphorus-carbon system: Part 3 - Metallography of low carbon iron-phosphorus alloys. Mater Sci Technol 16(3): 291-303

StrÁnskÝ K, SouchopovÁ V, LudIKOVSKÝ K (1978) Pokusné tavby na prímou výrobu železa z rud $v$ šachtových pecích na Blanensku. Slévárenství 26(11): 464-467

StrÁnskÝ K, Souchopová V, MeRTA J (2000) Rekonstrukce pochodů přímé výroby železa z rud. Archeol techn 11: $12-21$
SvobodA R (2014) Charakterizace železářských strusek z pokusné tavby realizované Technickým muzeem v Brně v r. 2012. MS, bakalářská práce, PřF UP Olomouc

ZMEŠKALOVÁ B. (2010) Mineralogické studium artefaktů po železářské výrobě v okolí Bystřice pod Hostýnem. MS, diplomová práce, PřF UP Olomouc 